Journal of Health Policy and Management (2016), 1(2): 78-94

https://doi.org/10.26911/thejhpm.2016.01.02.03

\title{
Relationship between Motivation, Competence, Workload, and Nurse Performance at Dr. Soediran Mangun Sumarso Hospital, Wonogiri, East Java
}

\author{
Agus Sutarto'), Hermanu Joebagio'), Pawito3) \\ 1)Dr. Soediran Mangun Sumarso Hospital, Wonogiri, East Java \\ 2)Faculty of Teaching and Educational Sciences, Universitas Sebelas Maret \\ 3)Faculty of Social and Political Sciences, Universitas Sebelas Maret
}

\begin{abstract}
Background: Health workerperformanceis one of the key elements that determine the quality of hospital service. Health worker performance therefore is the target for improvement. This study aimed to analyze the relationship between motivation, competence, workload of nurses, and nurse performance.

Subjects and Method: This was an analytical observational study with cross sectional design. This study was conducted at Dr. Soediran Mangun Sumarso Hospital, Wonogiri, Indonesia. A total of 50 nurses wereselected for this study.Theindependent variables were of motivation, competence, and workload. The dependent variable was performance of nurse. The data were collected by a questionnaire and analyzed by a multiple linear regression.

Results: This study did not find relationship between motivation and performance of nurse $(b=$ 0.02 ; $95 \% \mathrm{CI}=-0.19$ to $0.24 ; \mathrm{p}=0.823)$. Similarly there was no relationship workload and performance of nurse $(\mathrm{b}=0.05 ; 95 \% \mathrm{CI}=-0.15$ to $0.26 ; \mathrm{p}=0.607)$. There was a positive and statististically significant relationship between competence and performance of nurse $(b=1.10 ; 95 \% \mathrm{CI}=1.75$ to $0.46 ; \mathrm{p}=0.001$ ).
\end{abstract}

Conclusion: There is a positive and statistically significant relationship between competence and performance of nurse.

Keywords: motivation, competence, workload, performance, nurse

\section{Correspondence:}

Agus Sutarto. Dr. Soediran Mangun Sumarso Hospital, Wonogiri, East Java. Email: agus_skh70@yahoo.co.id.

\begin{abstract}
BACKGROUND
$\overline{\text { Hospitals as health service institutions }}$ must respond/responsive and be productive in meeting the needs of quality health services. The quality of health services should refer to the performance of health services. Complex services need to be professionally managed towards their human resources. The more perfect the appearance of health services, the more perfect the quality (Groves, 2014). One element that greatly determines the quality of hospital health services is health workers. The largest proportion of health workers in hospitals is
\end{abstract}

nurses, which is almost more than 50\% of all human resources hospital. Given that the important role they have, nurses are required to have intellectual, interpersonal, technical and moral abilities. It aims to maintain and improve the quality of health services (Darmayanti, 2014).

The qualities of professional nursing care services are the targets to be achieved to improve quality in hospitals. This can be achieved through good nurse performance which will have implications for good service. The several factors that influence a nurse's performance include individual 
factors, psychology and organization. Individual factors, for example, are motivation to improve the efficiency, effectiveness and performance of nurses so that they can improve the quality of services to the community (Nikpeyma, 2014).

In addition, the competencies possessed by nurses also affect the quality of services provided. Competent nurses are able to provide safe care in accordance with the responsibilities set by the nursing profession (Groves, 2014).

Organizational factors, for example, are workloads that have a close relationship with the quality of nurse performance. The number of tasks and responsibilities given to nurses can cause the results of services achieved to be less than optimal (Long, 2014). The development of competencies, motivations and workloads that are in accordance with the main tasks and functions, the quality of the performance of the nursing profession will be maximally focused on the professionalism in the field of nursing.

Based on the preliminary studies that the authors did, the profile of the efficiency of the Dr. Soediran Mangun Sumarso hospital in 2014 obtained bed occupancy ratio (BOR) data by $68.3 \%$ (ideally $60 \%-85 \%$ ), average length of stay (ALOS) 4 days (ideally 6-9 days), turn over interval (TOI) 2 days (ideally 1-3 days), bed turn over (BTO) 70 (ideally 40-50 times), and the number of hospitalized clients reaches 17,272 people.

The number of nurses on duty in the inpatient installation was 138 out of a total of 241 nurses on duty at this hospital. The data shows that hospitals can be used properly by the community in health services. This means that the workload of nurses is huge and demands for improving nurse performance are urgently needed.

Based on the background above, the author became interested in conducting study on the relationship between motivation, competence, workload of nurses and the performance of nurses at the Inpatient Installation of Dr. Soediran Mangun Sumarso hospital because of the high demand for quality nurse performance even though the motivation, competence, and workload of each nurse is different. This can affect the quality of health services provided for the community.

Motivation comes from the Latin word, movere, which means encouragement or driving force (Hendrarni, 2009). Motivation is the desire found in an individual which stimulates him to take action (Andayani, 2014). Whereas according to Tawale (2011), motivation is interpreted as a psychological need that has motivated work patterns or directions that exist within individuals that must be fulfilled so that their mental life is maintained, that is always in a comfortable balanced state (homeostasis, equilibrium).

Motivation strive to optimize the potential of employees to be able to work well, willing to work together to encourage improvement in employees' performance, so that they can be able to successfully achieve and realize predetermined goals (Toode, 2015). The strong or weak the work motivation also determines the size of his achievement. Higher work motivation makes a person has a high enthusiasm to provide the best service in order to achieve maximum performance.

Motivation in this study was developed based on McClelland's theory in Borkowski (2015) that grouped into three human needs:

\section{The need for achievement}

The need to become superior or successful. High achievers tend to look for challenging tasks, assume personal responsibility for their performance, and need feedback to confirm their success (Yanti, 2013). 
Journal of Health Policy and Management (2016), 1(2): 78-94

https://doi.org/10.26911/thejhpm.2016.01.02.03

\section{The need for power}

Individual needs to influence others can be positive or negative. This need appears to someone who wants to influence others.

\section{The need for affiliation}

Individual needs to be liked and recognized by others. This need encourages someone to interact with each other.

\section{Competence}

Competence can be interpreted as the ability of a person which can be observed through knowledge, skills, and attitudes in completing a job or task with a set of performance standards (INNA, 2012). Competence in health services is used to define the professionalism of health workers by referring to certain standards as expectations of performance of these officers by using evidence based health science (Tafwidhah, 2010). Elements of competence including: knowledge, attitude, and skill (Azwar, 2011).

\section{Workload}

Workload is the ability of the body of the worker to accept the work (Choi, 2014). Every workload received by a person must be appropriate and balanced with the physical and psychological abilities of workers (Manuho, 2015).

Nursing staff workload is influenced by its function to carry out nursing care and its capacity to perform this function. The workload of nurses in regional hospitals includes reviewing, planning, and eva-luating basic care for both individuals and community groups. The other task is to take care of sick people, protect patients from transmission and seek rehabilitation, and make simple records of patient development (Batuah, 2012).

The nurse is in charge of caring for the patient within 24 hours by applying nursing care, from the time the patient enters the hospital until discharged from the hospital. Several aspects that are used to assess the workload of nurses:

\section{Physical Aspects}

The workload is determined from the tasks carried out based on the main function and additional tasks including the number of patients to be treated and their work ca-pacity in accordance with the education obtained (Manuho, 2015)

\section{Psychological aspects}

Mental/psychological aspects emphasize more on interpersonal relationships between nurses and room heads, nurses and other nurses, and nurses and patients (Manuho, 2015).

\section{Aspects of Working Time}

Aspects of working time is the working time used in carrying out basic duties and functions of nurses and additional tasks in accordance with working hours that take place every day. If the working time that must be borne by the nurse exceeds its capacity, it will adversely affect the productivity of the nurse.

\section{Nurse Performance}

Performance is the result of the work of the personnel both quantity and quality in an organization (Makta, 2013). Good performance will be influenced by two things, namely the level of ability/ competence and good work motivation. A person's abi-lity is influenced by his understanding of the type of work and the skill to do it.

Therefore, someone must be able to improve their abilities and skills. In addition, the contribution of work motivation towards performance cannot be ignored. Although the ability of employees is very good, if their work motivation is low, it will result in low performance (Sinambela, 2012).

The success of nursing services is largely determined by the performance of the nurses. The level of nurse performance can be measured based on several indicators. 
The performance indicators include quality of work, efficiency in carrying out tasks, work discipline, initiative, thoroughness, leadership, and honesty of creativity. The demands and needs of quality nursing care in the future are challenges that must be prepared seriously, handled fundamentally, and carried out in a directed and earnest manner by the hospital (Yanidrawati, 2011).

This study aims to prove the existence of various factors related to the performance of nurses in the Inpatient Installation Dr. Soediran Mangun Sumarso hospital.

\section{SUBJECTS AND METHOD \\ 1. Study Design \\ The design of the study used was analytical study with a cross sectional approach. The study was conducted at Dr. Soediran Ma- ngun Sumarso hospital, Wonogiri, East Ja- va for 5 months.}

\section{Population and Sampling}

The population of this study was nurses who worked in inpatient installation at Dr.
Soediran Mangun Sumarso hospital, as many as 138 nurses.In this study, the subjects were 50 nurses.

\section{Study Variables}

The dependent variable was nurse performance. The independent variables were motivation, competence, and workload.

\section{Study Instruments}

The datawere colllected by questionnaires and secondary data from the medical record section.

\section{Data Analysis}

Data were analyzed by a multiple linear regression

\section{RESULTS}

\section{Univariate Analysis}

The subject of study was male and female nurses.The male nurses were $22.0 \%$ and the female nurses were $78.0 \%$. In the age category, the highest number of nurses who were working at the hospital was $\geq 35$ years old (62.0\%). While nurses aged $<35$ years old were $38.0 \%$.

\section{Table 1. Characteristics of the subject of categorical data}

\begin{tabular}{|c|c|c|c|}
\hline Variables & 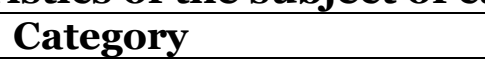 & Frequency & Percent \\
\hline \multirow[t]{2}{*}{ Age } & $\leq 35$ years & 19 & 38.0 \\
\hline & > 35 years Total & 31 & 62.0 \\
\hline \multirow[t]{2}{*}{ Gender } & Male & 11 & 22.0 \\
\hline & Female Total & 39 & 78.0 \\
\hline \multirow{4}{*}{ Education } & Health nursing school & 1 & 2.0 \\
\hline & Diploma of Nursing & 26 & 52.0 \\
\hline & Bachelor degree of Nursing & 20 & 40.0 \\
\hline & Professional Nurse & 3 & 6.0 \\
\hline \multirow[t]{2}{*}{ Length of work } & $<5$ years & 5 & 10.0 \\
\hline & $\geq 5$ years & 45 & 90.0 \\
\hline \multirow[t]{2}{*}{ Training } & $<3$ times & 38 & 76.0 \\
\hline & $\geq 3$ times & 12 & 24.0 \\
\hline \multirow[t]{2}{*}{ Motivation } & Low & 25 & 50.0 \\
\hline & High & 25 & 50.0 \\
\hline \multirow[t]{2}{*}{ Competency } & Not good & 22 & 44.0 \\
\hline & Well & 28 & 56.0 \\
\hline \multirow[t]{3}{*}{ Workload } & Low & 6 & 12.0 \\
\hline & Enough & 30 & 60.0 \\
\hline & High & 14 & 28.0 \\
\hline \multirow{2}{*}{$\begin{array}{l}\text { Nurse } \\
\text { performance }\end{array}$} & Not good & 18 & 36.0 \\
\hline & Well & 32 & 64.0 \\
\hline
\end{tabular}


The level of participation of nurses in training was still small. This was shown in Table 1, where most nurses attended training $<3$ times as much as $76.0 \%$ while nurses who attended training 3 times reached $24.0 \%$. In terms of education level, the majority of nurses graduated from Diploma of Nursing as much as $52.0 \%$ and Bachelor degree of Nursing reached 40.0\%. Nurses who took nursing professional education were still small (6.0\%). Table 1 shows that most nurses had worked 5 years (90.0\%).

In Table 1 it is known that the work motivation of the nurse inDr. Soediran Mangun Sumarso hospital was low at 50.0\%, while nurses who had high work motivation also reached 50.0\%. The competencies of nurses were mostly in the good category, which was $56.0 \%$, while nurses who had low competence were $44.0 \%$.

The workload of nurses at Dr. Soediran Mangun Sumarso hospitalwas included in the low category by $12.0 \%$, medium workload was $60.0 \%$ and high workload category was $28.0 \%$. Nurse performance inDr. Soediran Mangun Sumarso hospital showed good results by $64.0 \%$ (Table 1 ), while nurses with poor performance were $36.0 \%$.

\section{Bivariate Analysis}

a. The Relationship between Motivation and Nurse Performance.

Figure 1 shows there is no correlation between motivation and nurse performance with $\mathrm{r} 2=0.467$. This meantthat the performance of a nurse at Dr. Soediran Mangun Sumarso hospital is influenced by motivation.

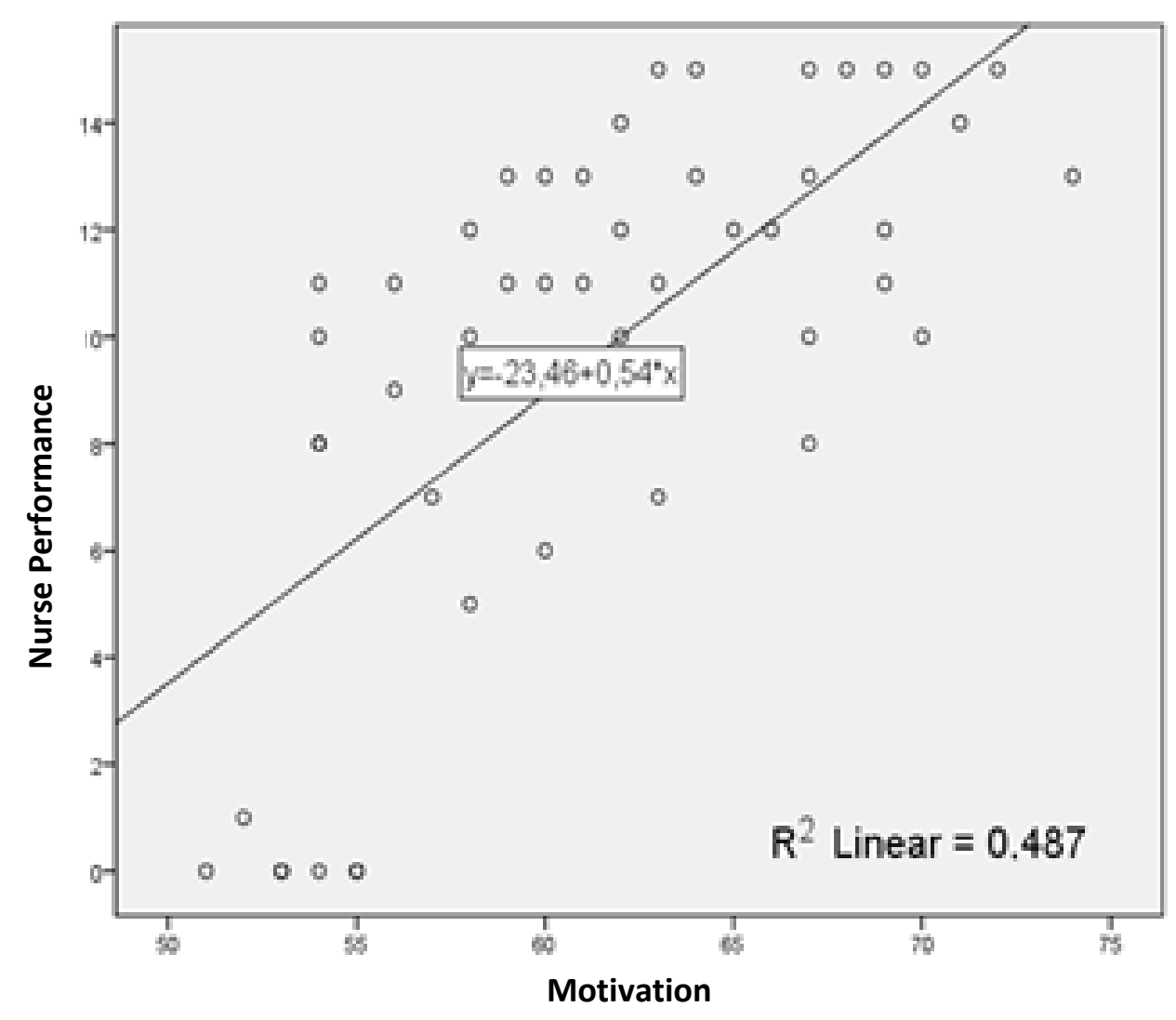

Figure 1. Relationship between motivation and nurse performance 


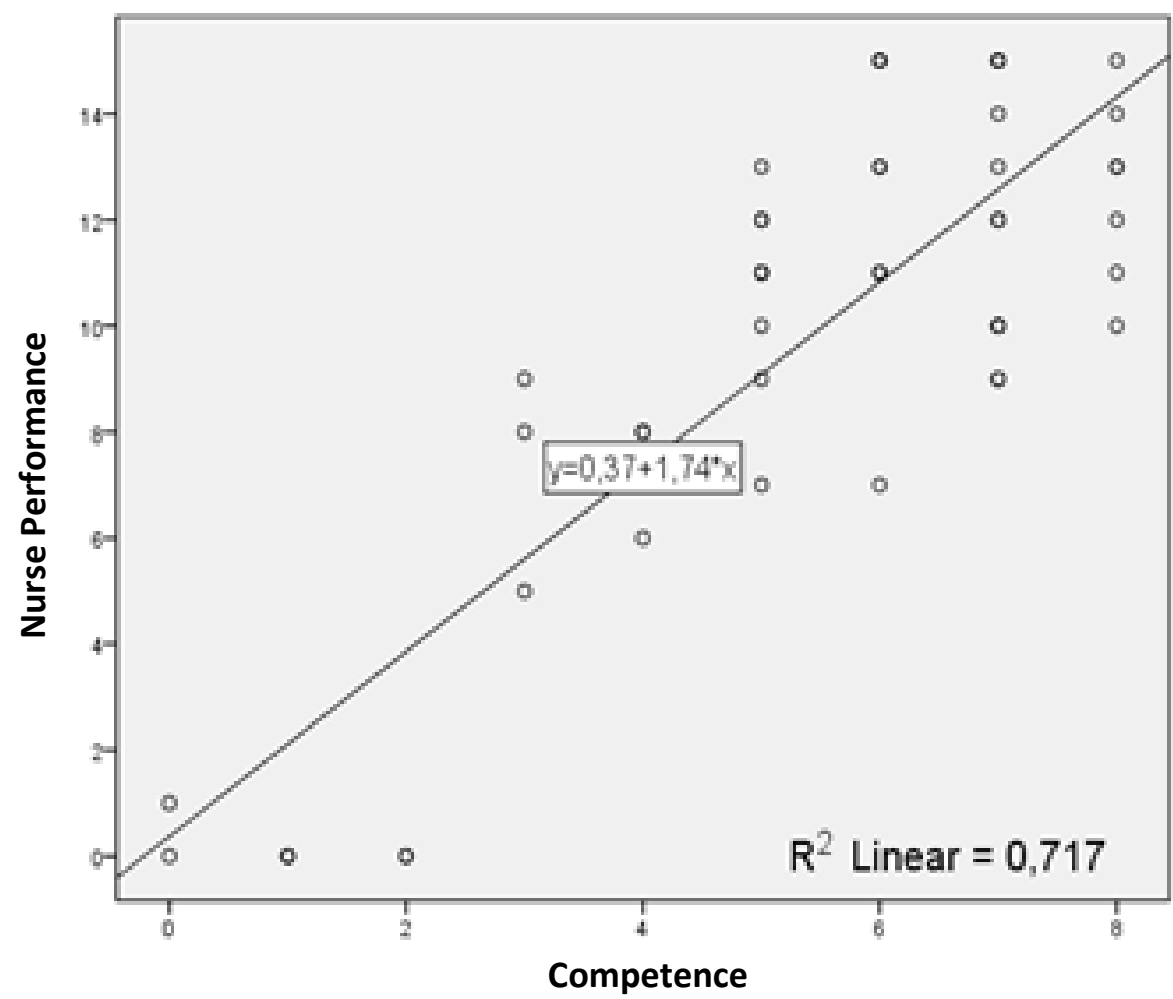

Figure 2. Relationship of competence with nurse performance

b. Relationship Between Competence and Nurse Performance

The relationship between competence and nurse performance is shown in Figure 2. In the figure, there is a positive relationship between competence and nurse performance with a value of $\mathrm{r} 2=0.717$. This meant that the better the competencies possessed by a nurse, the better the nurse's performance in providing nursing services.

c. Relationship between Workload and Nurse Performance

The relationship between nurse workload and nurse performance by category was shown in Figure 3. The low workload category $(<42)$ had a minimum performance value of $\mathrm{o}$ and a maximum performance value of 5 .

Medium workload categories (42-52) had a minimum performance value by 10 and a maximum performance value by 14 , while a high workload category $(\geq 53)$ had a minimum performance value of 6 and a maximum score of 11 .

\section{Multivariate Analysis}

The relationship betweenmotivation, competence, and workload and the performance of nurses at the inpatient installation at Dr. Soediran Mangun Sumarso hospital, were analyzed by multiple linear regression analysis model with the help of SPSS 18.0 program. The results of multiple linear regression analysis can be seen in Table 2.

There was a positive, linear and statistically significant relationship between motivation and performance of nurses at inpatient installations. Each unit increase of motivation would increase performance by 0.15 units $(\mathrm{b}=0.15 ; 95 \% \mathrm{CI}=0.02$ to 0.28 ; $\mathrm{p}=0.022)$. There was a positive, linear, and statistically significant relationship between the competence and performance of nurses in the inpatient installation. Each unit in- 
crease of competency would increase performance by 1.22 units $(\mathrm{b}=1.22 ; 95 \% \mathrm{CI}=$ 0.86 to $1.57 ; \mathrm{p}<0.001)$. There was a positive relationship, in the form of a linear curve and an inverted $\mathrm{U}$ between the workload and the performance of nurses in inpatient installation.

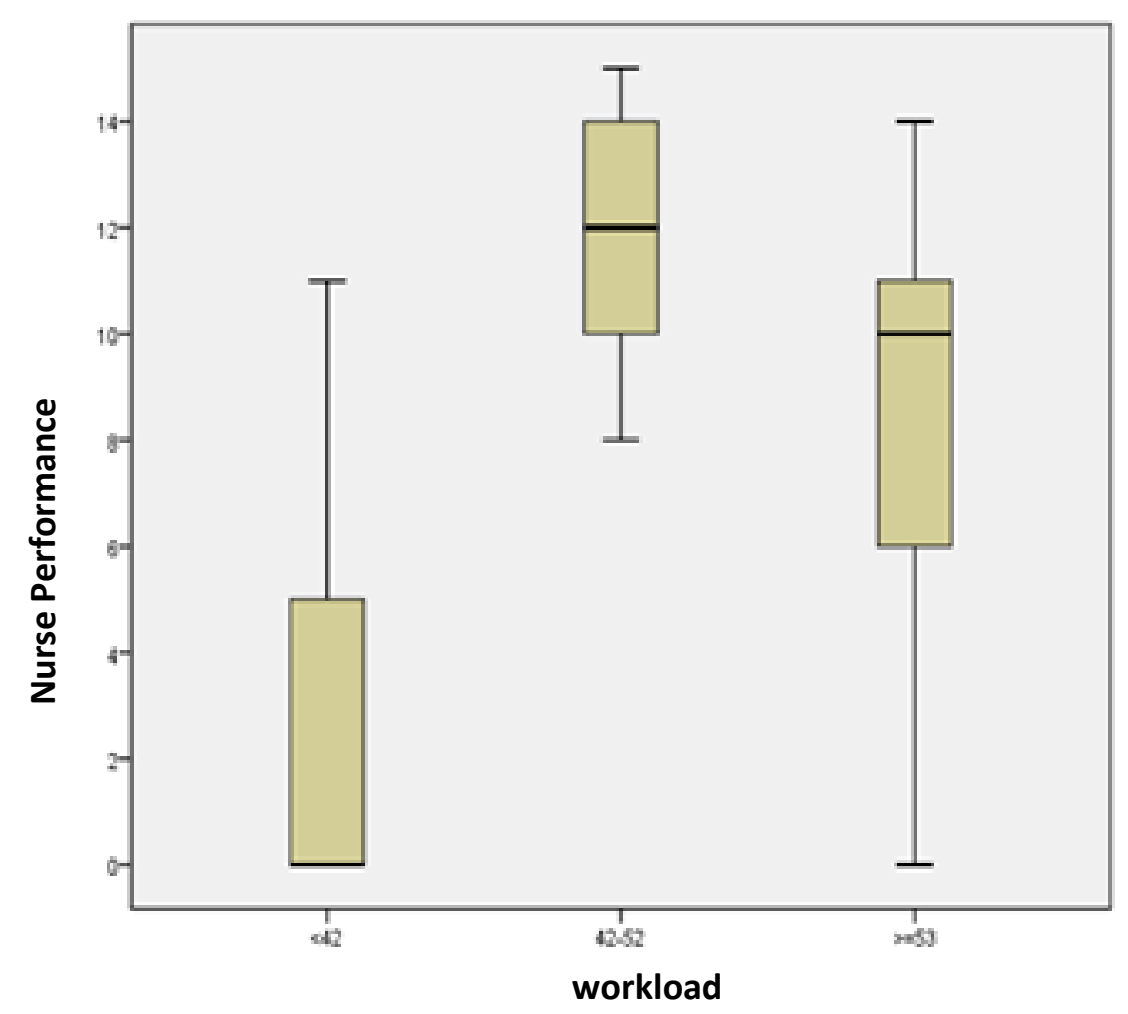

Figure 3. Relationship between workload and nurse performance

Table 2.The results of multiple linear regression analysis about the relationship between motivation, competence, and workload and nurse performance.

\begin{tabular}{|c|c|c|c|c|}
\hline \multirow[b]{2}{*}{ Independent Variables } & \multirow[b]{2}{*}{ b } & \multicolumn{2}{|c|}{$95 \%$ CI } & \multirow[b]{2}{*}{$\mathbf{p}$} \\
\hline & & $\begin{array}{c}\text { Lower } \\
\text { limit }\end{array}$ & $\begin{array}{l}\text { Upper } \\
\text { limit }\end{array}$ & \\
\hline Constants & -8.41 & -15.22 & -1.61 & 0.017 \\
\hline Motivation & 0.15 & 0.02 & 0.28 & 0.022 \\
\hline Competencies & 1.22 & 0.86 & 1.57 & 0.001 \\
\hline Workload & 0.81 & -1.37 & 2.99 & 0.459 \\
\hline $\begin{array}{l}\text { Workload category } \\
\text { n observation }=50 \\
\text { Adjusted } \mathrm{R}^{2}=81.25 \% \\
\mathrm{p}=0.004\end{array}$ & 3.33 & 1.16 & 5.49 & 0.003 \\
\hline
\end{tabular}

Nurses with workloads on average had a performance score of 3.33 units higher than light workloads and statistically significant $(\mathrm{b}=3.33$; 95\% CI= 1.16 to 5.49 ; $\mathrm{p}=0.003$ ). Nurses with heavy workloads on average had a performance score of 0.81 units higher than light workloads, but these differences were not statistically significant ( $b=0.81 ; 95 \% \mathrm{CI}=-1.37$ to $2.99 ; \mathrm{p}=0.459$ ). Adjusted $\mathrm{R}^{2}=81.25 \%$ implied that the three independent variables in the linear regression model, namely motivation, competence and workload, were jointly able to explain variations in nurse performance by $81.25 \%$. 
The $\mathrm{p}<0.001$ meant that overall the three independent variables had a statistically significant relationship with nurse performance.

\section{DISCUSSION}

Nursing services in hospitals are part of a comprehensive and continuous health service and play an important role in efforts to maintain and improve the quality of health services. The quality of health services influences the quality of hospital services and even becomes one of the determining factors for evaluating the performance of hospital health workers in the eyes of the community (Langingi, 2015).

Quality and professional nursing care services are targets to be achieved to improve quality in hospitals. This can be achieved through good nurse performance which will have implications for good service. Several factors that influence a nurse's performance include individual factors, psychology, and organization. Individual factors, for example, are motivation to improve the efficiency, effectiveness, and performance of nurses so that they can improve the quality of services to the community (Nikpeyma, 2014).

In addition, the competencies possessed by nurses also affect the quality of services provided. Competent nurses are able to provide safe care in accordance with the responsibilities set by the nursing profession (Groves, 2014). Organizational factors, for example, are workloads that have a close relationship with the quality of nurse performance. The number of tasks and responsibilities given to nurses can cause the results of services achieved to be less than optimal (Long, 2014). The development of competence, motivation, and workload in accordance with the main tasks and functions will make the quality of the nursing profession's performance to be maximized focusing on the professionalism in the nursing world.

Improving nurse performance is determined by work motivation, competence and workload that are owned by nurses. Work motivation greatly affects the performance of nurses, because without encouragement from within a nurse, the work results shown will not be maximal. Competence is the basic ability of a nurse that is used as a reference to remain effective in the workplace in any situation that is considered influential on the performance of nurses. Workload can affect performance such as the number of tasks that must be completed by a nurse during a particular shift (Satria, 2013).

From the results of testing the hypothesis in Table 2, it is known that the study proved significantly that there is a relationship between motivation, competence, workload and nurse performance in the inpatient care Dr. Soediran Mangun Sumarso hospital $(\mathrm{p}<0.001)$. The value of $\mathrm{R}^{2}=$ $81.25 \%$ implies that the variables of motivation, competence and workload together can explain the variation in nurse performance by $81.25 \%$.

Nurses provide nursing services in hospitals for 24 hours a day, and have constant contact with patients. Therefore hospital nursing services are an integral part of health services. Contributions given by nurses greatly determine the quality of hospital services. Efforts to improve hospital services must be followed by improving the quality of nursing services (Hendrarni, 2008).

Attention to increasing nurse performance in providing nursing services in hospitals is based on motivation, competence, and workload. These factors can shape the performance of nurses in hospitals so that it supports the implementation of duties and 
Journal of Health Policy and Management (2016), 1(2): 78-94

https://doi.org/10.26911/thejhpm.2016.01.02.03

responsibilities in providing nursing services (Hendrarni, 2008).

Employee performance is a synergistic result of a number of factors (Yanidrawati, 2011). In this study only competency variables affected nurse performance, while work motivation and workload did not affect nurse performance. Nurse performance is a synergistic result of a number of factors (Yanidrawati, 2011). In this study, there are three factors that influence the performance of nurses so that they are in a good category (Table 1), including individual factors, psychological factors and organizational factors.

Individual factors are internal factors within workers, such as good competence and high education (Table 1) will have an impact on good performance as well. Psychological factors are employees' perceptions of their work. Nurses have a high sense of responsibility towards their work in providing nursing services because it involves patient safety. Therefore, nurses will provide good performance because they carry out their responsibilities. Organizational factors, namely the existence of organizational demands on employees that will affect performance. Dr. Soediran Mangun Sumarso hospital requires nurses to be able to provide quality and professional nursing care services because hospitals want to achieve the target in order to improve the quality of hospital services.

\section{REFERENCE}

Andayani SA (2014). Hubungan kompensasi, kompetensi dan motivasi dengan kinerja dosen di STIKES Nurul Jadid Paiton Probolinggo. Surakarta, Universitas Sebelas Maret. Tesis.

Azwar S (2010). Sikap Manusia, Teori dan Pengukurannya. Yogyakarta: Pustaka Mulia.24-6.
Azwar (2010). Tes Prestasi: Fungsi dan Pengembangan Pengukuran Prestasi Belajar. Yogyakarta: Pustaka Mulia. 173-80.

Batuah N (2012). Hubungan beban kerja perawat terhadap kinerja perawat pelaksana dalam pemberian pelayanan kesehatan di ruang rawat inap Rumah Sakit Islam Faisal Makasar. Makasar, STIKES Nani Hasanuddin Makasar. Skripsi.

Borkowski N (2015). Manajemen Pelayanan Kesehatan: Perilaku Organisasi. Jakarta: EGC.115-24.

Choi SY, Kim KS (2014). The effects of work characteristics, supervision and cultural competence on nurses' burnout. International Journal of Bioscience and Biotechnology. 5(4): 187-200.

Darmayanti NNT, Oktamianti P (2014). Analisis kompetensi perawat ruang intensif (Intensive Care Unit) Rumah Sakit Umum Tabanan Tahun 2013. Jurnal Sumber Daya Manusia Kesehatan. 1(1): 77-104.

Darmayanti R (2015). Hubungan Motivasi Kerja dengan Kinerja Perawat Rawat Inap di Rumah Sakit Sultan Syarif Mohamad Alkadrie Pontianak. Pontianak, Universitas Tanjungpura. Skripsi.

Groves W (2014). Professional Practice Skill for Nurses. Continuing Professional Development. 29(1): 51-59.

Hendrarni W (2008). Pengaruh Motivasi Kerja terhadap Kinerja Asuhan Keperawatan dalam Pengkajian dan Implementasi Perawat Pelaksana di Rumah Sakit Bhayangkara Medan. Medan, Universitas Sumatera Utara. Skripsi.

Langingi ARC (2015). Hubungan Faktor Internal dan Eksternal dengan Kinerja Perawat Pelaksana di Instalasi RawatInap C RSUP Prof. Dr. R. D. Kan- 
Sutarto et al./Relationship Between Motivation, Competence, Workload, and Nurse Performance

dou Manado. Manado, Universitas Sam Ratulangi. Tesis.

Long CS, Kowang TO, Ping TA, Muthuveloo $\mathrm{R}$ (2014). Investigation on The Impact of Job Stressors on Nurses in Malaysia. Asian Social Science. 10(4): 67-77.

Makta LO, Noor NB, Kapalawi I (2013). Pengaruh Motivasi Kerja dengan Kinerja Perawat Pelaksana di Unit Rawat Inap RS Stella Maris Makasar Tahun 2013. 1-12.

Manuho E, Warouw H, Hamel R (2015). Hubungan Beban Kerja dengan Kinerja Perawat dalam Pemberian Asuhan Keperawatan di Instalasi Rawat Inap CI RSUP Prof.Dr.R.D. Kandou Manado. Ejournal Keperawatan. 3(2): 1-6.

Nikpeyma N, Saeedi ZA, Azargashb E, Majd HA (2014).Problems of clinical nurse performance appraisal system-A qualitative study. Asian Nursing Research. 8: 15-22.

Satria W (2013). Hubungan beban kerja dengan kinerja perawat dalam mengimplementasikan patient safety di $\mathrm{Ru}-$ mah Sakit Universitas Hasanuddin tahun 2013. Makasar, Universitas Hasanudin. Skripsi.
Sinambela LP (2012). Kinerja Pegawai: Teori, Pengukuran dan Implikasi. Yogyakarta: GrahaIlmu.

TafwidhahY(2010). Hubungan kompetensi perawat puskesmas dan tingkat keterlaksanaan kegiatan perawatan kesehatan masyarakat (Perkesmas) di Kota Pontianak. Jakarta,Universitas Indonesia. Tesis.

Tawale EN, Budi W, Nurcholis G (2011). Hubungan antara motivasi kerja perawat dengan kecenderungan mengalami burnout pada perawat di RSUD Serui-Papua. Jurnal Insan. 13(2): 7484.

Toode K (2015). Nurse's Work Motivation. Finlandia, University of Tampere. Dissertation.

Yanti RI, Warsito BE (2013). Hubungan Karakteristik Perawat, Motivasi dan Supervisi dengan Kualitas Dokumentasi Proses Asuhan Keperawatan. Jurnal Managemen Keperawatan. 1(2): 107-114.

Yanidrawati K (2011). Hubungan Kepuasan Kerjadengan Kinerja Perawat di Ruang Rawat Inap Rumah Sakit Umum Daerah Kabupaten Bekasi. Bandung, Universitas Padjadajaran. 